\title{
The Effect of Various Types of Natural Sweeteners in Agar with Rice Bran Addition on Organoleptic and Physicochemical Characteristics
}

\author{
Bangun Naomi Marcelina ${ }^{\#}$, Silvi Leila Rahmi ${ }^{\#}$, Rahayu Suseno \\ \# Teknologi Hasil Pertanian, Fakultas Teknologi Pertanian, Universitas Jambi, Kampus Pondok Meja Jl Tribrata Km 11, \\ Jambi, Indonesia \\ Email: rahayususeno@gmail.com
}

\begin{abstract}
This research was conducted in two stages, namely the first stage, looking for the best concentration of natural sweetener with organoleptic. Second stage analyzed the physicochemical characteristics using the best concentration of first stage. This research was carried out using a Completely Randomized Design, with various natural sweeteners consisting 6 levels, namely: stevia sweetener $(0.05 \%, 0.75 \%, 0.10 \%)$, sorghum sugar $(10 \%, 15 \%, 20 \%)$, corn sugar $(10 \%, 15 \%, 20 \%)$, coconut sugar $(14 \%, 15 \%, 16 \%)$, palm sugar $(7.5 \%, 10 \%, 12.5 \%)$, and honey $(15 \%, 25 \%$, $35 \%$ ) and 3 replications so that 18 experimental units. The addition of various types of natural sweeteners significantly affected the hedonic test (taste and overall acceptance), water content, $\mathrm{pH}$, total dissolved solids, total sugar, and color but did not significantly affect the hedonic quality test (texture), hedonic test (texture and color), crude fiber content, syneresis and gel hardness.
\end{abstract}

Keywords - Agar, Natural Sweeteners, Rice Bran

\section{INTRODUCTION}

Functional food is processed food that has one or more food components which, based on scientific studies, have certain physiological functions outside their basic functions, are proven to be harmless, and beneficial to health (BPOM, 2005). The commodity that gets attention as functional food is rice bran. Rice bran is one of the byproducts of the rice milling process. Rice bran has a fiber content in the form of cellulose of $8.7-11.4 \%$ and hemicellulose of 9.612.8\% (Azzmi, 2012).

Utilization of rice bran as processed food has not been done much. Therefore, making processed food from rice bran needs to be done, one that can be made is agar products. The addition of rice bran can increase fiber content in agar and can make agar products enriched with secondary metabolites in the form of saponins, alkaloids, tannins, and flavonoids (Moko et al., 2014), but rice bran has a bitter taste aftertaste. Bitter taste is caused by the presence of saponin in rice bran (Kusumastuti and Ayustaningwarno, 2013).

So far, the use of cane sugar in making agar products is not good for health because cane sugar has a glycemic index of 75 , while the limit of glycemic sugar levels that are good for health is 40 (Yanto et al., 2015). Therefore, it is necessary to add natural sweeteners with a low glycemic index but can cover the aftertaste produced from bran.
Research into making sweet pineapple jelly drink with the addition of stevia sugar with two factors. Concentration of carrageenan consisting of three levels of $0.075 \% ; 0.085 \%$ and $0.095 \%$ and stevia sugar concentration consisting of three levels of $0.05 \% ; 0.075 \%$ and $0.1 \%$. The best results are carrageenan concentration of $0.085 \%$ and stevia sugar concentration of $0.075 \%$ which is the combination that produces pineapple jelly drinks that are most favored by panelists (Cyntia, 2018).

The sugar content of sorghum mainly comes from fructose and cellobiose so that sweeteners made from sorghum can be consumed by diabetics without causing side effects, but the starch content of the sorghum sap is relatively high so that it inhibits the crystallization process of sorghum sap into crystalline sugar (Irawan and Sutrisna , 2011).

Corn sugar is glucose taken from corn. Sweet corn has a relatively high sweet taste but low fat content, so it is suitable to be processed into sugar for diabetics. The sweet taste of corn sugar is around $5-6 \%$ which is more than ordinary corn flavor with sugar content of 2-3\% (Sirajuddin, 2010).

Research on making jelly drinks with the addition of coconut sugar with a concentration of $14 \% ; 15 \%$; 16\%. From the research it was concluded that jelly drinks using liquid coconut sugar and coconut sugar with concentrations of $15 \%$ and $16 \%$ are generally preferred by panelists, but jelly drinks that use coconut sugar with a 
concentration of $14 \%$ are less favored by panelists (Yanto et al. 2015).

Research on nata de seaweed (Eucheuma cottonii) with a difference in seaweed concentration of $1 \% ; 2 \% ; 3 \%$ and palm sugar concentration $7.5 \%$; $10 \% ; 12.5 \%$. Based on the pair differentiation test that has been done, the results show that there are no differences in appearance, aroma and taste between nata de seaweed and nata de coco commercial (Syukroni et al. 2013).

Research on making tomato velva (Lycopersicum esculentum Mill) with honey sweetener with a concentration of $15 \% ; 25 \%$ and $35 \%$, shows that the sweetness intensity test of tomato velva with $15 \%$ honey concentration has a lower sweetness level than $25 \%$ sucrose, while tomato velva with $25 \%$ honey concentration and $35 \%$ has a higher sweetness level than sucrose $25 \%$ (Sapriyanti et al. 2014).

The research aims to determine the best concentration of various types of natural sweeteners and determine the effect of various types of natural sweeteners on agar with the addition of bran to organoleptic and physicochemical properties.

\section{MATERIAL AND METHODS}

\section{A. Material}

The materials used are rice bran from the rice mill

of Tunas Harapan Farmer Group, Muaro Jambi Regency, agar powder, water, vanilla, sweetener stevia, sorghum sugar, corn sugar, coconut sugar, palm sugar, and honey. Materials for chemical analysis are standard buffer $\mathrm{pH} 4$ and $\mathrm{pH} 7$, aquadest, $\mathrm{HCl} 25 \%, \mathrm{NaOH}$, phenolphthalein, phenol $5 \%$ solution, sulfuric acid, $\mathrm{H}_{2} \mathrm{SO}_{4} \quad 0.3 \mathrm{~N}$ and Whatman filter paper No. 41 .

\section{B. Methods}

Stage I. Preparation of agar with the addition of bran (Mithania, 2017 with modification) for organoleptic testing.

Rice bran for 10 minutes is roasted at a temperature of $80-90^{\circ} \mathrm{C}$, sieved using a 100 -mesh sieve. $325 \mathrm{~mL}$ of water is heated. After that, natural sweeteners are added according to their treatment and concentration which can be seen in Table $\mathbf{1}$, commercial agar powder as much as $3.5 \mathrm{~g}$, vanilla $0.5 \mathrm{~g}$, and roasted rice bran as much as $15 \mathrm{~g}$. All ingredients are stirred until boiling. The agar is poured into a plastic cup and allowed to stand until it hardens. After that the organoleptic test was carried out to get the best concentration of each treatment.

Table 1

Types and Concentrations of Natural Sweeteners

\begin{tabular}{cc}
\hline $\begin{array}{c}\text { Types of Natural } \\
\text { Sweeteners }\end{array}$ & Consentration (\%) \\
\hline Stevia sweetener & 0,$05 ; 0,075 ; 0,10$ \\
Sorghum sugar & $10 ; 15 ; 20$ \\
Corn sugar & $10 ; 15 ; 20$ \\
Coconut sugar & $14 ; 15 ; 16$ \\
Palm sugar & 7,$5 ; 10 ; 12,5$ \\
Honey & $15 ; 25 ; 35$ \\
\hline
\end{tabular}

Stage II. Making agar with the addition of bran (Mithania, 2017 with modification) for analysis. Preparation of agar is the same as stage I, but at this stage it uses the best concentration of each type of natural sweetener. The best concentration can be seen in table 2 .

Table 2

The Best Concentrations of Natural Sweeteners

\begin{tabular}{cc}
\hline $\begin{array}{c}\text { Types of Natural } \\
\text { Sweeteners }\end{array}$ & Concentration (\%) \\
\hline Stevia sweetener & 0,10 \\
Sorghum sugar & 20 \\
Corn sugar & 20 \\
Coconut sugar & 16 \\
Palm sugar & 12,5 \\
Honey & 35 \\
\hline
\end{tabular}

Table 3

Hedonic Quality Test Score and Hedonic Test Score

\begin{tabular}{|c|c|c|c|c|c|}
\hline \multirow[t]{2}{*}{ Skor } & \multicolumn{5}{|c|}{ Parameter } \\
\hline & $\begin{array}{c}\text { Texture } \\
\text { (Hedonic Quality) }\end{array}$ & Texture & Color & taste & Overall acceptance \\
\hline 7 & - & Really like & Really like & Really like & Really like \\
\hline 6 & - & Like & Like & Like & Like \\
\hline 5 & Very easily Break & Rather like & Rather like & Rather like & Rather like \\
\hline 4 & Easy to break & Neutral & Neutral & Neutral & Neutral \\
\hline 3 & Somewhat easily broken & Somewhat like & Somewhat like & Somewhat like & Somewhat like \\
\hline 2 & Not easily Broken & Dislikes & Dislikes & Dislikes & Dislikes \\
\hline 1 & Very easy to break & Very dislike & Very dislike & Very dislike & Very dislike \\
\hline
\end{tabular}

\section{Parameter Analysis}

Organoleptic Test

Organoleptic test was carried out in the first stage of research to get the best concentration of each treatment. The panelists used were 30 trained panelists who were from Agricultural Product Technology students, Faculty of Agricultural Technology, Jambi University. Panelists were asked to provide an assessment of the hedonic quality test (texture) in the range of 1-5 scale and the hedonic test (texture, color, taste and overall acceptance) in the range of scale 1-7 which can be seen in Table 3 .

\section{Water content}

The aluminum dish is roasted for 15 minutes and cooled in a desiccator for 10 minutes, then 
weighed. The sample was weighed as much as $2 \mathrm{~g}$ in a cup. The cup and contents are $105^{\circ} \mathrm{C}$ for 6 hours. The cup is transferred to the desiccator and then dried and weighed. The cup and its contents are dried again until a constant weight is obtained. Moisture content is calculated by the equation:

Water content $(\% b / b)$

$$
=W-\frac{\left(W_{1}-W_{2}\right)}{W} \times 100 \%
$$

Information:

$\mathrm{W}=$ weight of sample before drying $(\mathrm{g})$

$\mathrm{W} 1=$ sample weight and dry cup $(\mathrm{g})$

$\mathrm{W} 2$ = empty cup weight $(\mathrm{g})$

\section{Acidity (pH)}

The $\mathrm{pH}$ meter is calibrated using a buffer solution of $\mathrm{pH} 4$ and $\mathrm{pH}$ 7. The electrodes are rinsed with distilled water and dried. The crushed sample of $5 \mathrm{~g}$ was put into a $25 \mathrm{ml}$ beaker and the aquadest was added until it reached $25 \mathrm{ml}$. The $\mathrm{pH}$ meter electrode is dipped into the sample. The number displayed on the screen shows the agar $\mathrm{pH}$ value.

\section{Total Dissolved Solids}

The refractometer prism is rinsed with water and wiped with a soft cloth. The $5 \mathrm{~g}$ sample was crushed and then put into a $25 \mathrm{ml}$ beaker and added water until it reached $25 \mathrm{ml}$. The sample is dropped onto a refractometer prism. The number shown shows the TPT value in Brix units.

\section{Crude Fiber Content}

A sample of $1 \mathrm{~g}$ was put into a $300 \mathrm{ml}$ beaker, adding $50 \mathrm{ml}$ of $\mathrm{H}_{2} \mathrm{SO}_{4} 0.3 \mathrm{~N}$ to boil for 30 minutes. Add $50 \mathrm{ml}$ of $1.5 \mathrm{~N} \mathrm{NaOH}$ and boil again for 30 minutes. The liquid in the beaker is filtered with filter paper. Subsequently washed in succession with $50 \mathrm{ml}$ of hot water, $50 \mathrm{ml}$ of $\mathrm{H}_{2} \mathrm{SO}_{4} 0.3 \mathrm{~N}$ and $25 \mathrm{ml}$ of acetone. The residue along with the filter paper is roasted at $105^{\circ} \mathrm{C}$ until the weight is constant then weighed. After that it is put in the furnace at $105^{\circ} \mathrm{C}$ for 3-4 hours. Fiber content can be calculated by the equation:

$$
\begin{gathered}
\text { Crude fiber content }(\%)= \\
\frac{a-b-c}{w} \times 100 \%
\end{gathered}
$$

Note:

$\mathrm{a}=$ Weight of residue in filter paper dried $(\mathrm{g})$

$\mathrm{b}=$ Weight of residue that has been planted $(\mathrm{g})$

$\mathrm{c}=$ Weight of empty filter paper $(\mathrm{g})$

$\mathrm{w}=$ sample weight $(\mathrm{g})$

\section{Total Sugar}

a. Making a Standard Curve

Standard curves were made using standard glucose solutions of $0,10,20,30,40$ and $50 \mu 1$ glucose, each pipette as much as $1 \mathrm{ml}$ was inserted into a test tube. $5 \%$ phenol solution was added then stirred. Then quickly added concentrated $\mathrm{H}_{2} \mathrm{SO}_{4}$ solution. Leave for 10 minutes then stir. Placed in a water bath for 15 minutes. The absorbance was measured at $490 \mathrm{~nm}$.

\section{b. Sample Determination}

$1 \mathrm{ml}$ of diluted sample is then put into a test tube. $5 \%$ phenol solution was added then stirred. Then added concentrated $\mathrm{H}_{2} \mathrm{SO}_{4}$, left for 10 minutes then stirred. Placed in a water bath for 15 minutes. The absorbance was measured at $490 \mathrm{~nm}$.

\section{Syneresis}

Agar is put into a plastic cup weighing $40 \mathrm{~g}$ for each treatment. The water separated from the agar was separated, then weighed on the 0 th, 7 th, and 14 th days in storage. The level of syneresis is calculated by the formula:

$$
\text { Syneresis }=\frac{W_{1}-W_{2}}{W_{1}} \times 100 \%
$$

Note:

$\mathrm{W} 1=$ The initial weight of the gel

$\mathrm{W} 2=$ The final weight of the gel

\section{Color Analysis with Color Reader}

Samples are put in a uniform transparent plastic cup, the device is turned on by pressing the Power Switch and Lab button, then the cup is affixed to the optical head and press the measuring button, the results obtained include $\mathrm{L} *$ (lightness), a * (redness) and $\mathrm{b} *$ (yellowness). The color descriptions are presented in Table 4 as follows:

Table 4

Color Descriptions Based on $\mathrm{L} *, \mathrm{a} *$, and $\mathrm{b} *$ values

\begin{tabular}{cc}
\hline Score & Color Description \\
\hline L & 0 (black) -100 (white) \\
$+\mathrm{a}$ (positive) & $0-100$ for red \\
-a (negative) & $0-(-80)$ for green \\
$+\mathrm{b}$ (positive) & $0-70$ for yellow \\
$-\mathrm{b}$ (negative) & $0-(-70)$ for blue \\
\hline
\end{tabular}

Furthermore, ${ }^{\circ}$ Hue is calculated from the values $\mathrm{a} *$ and $\mathrm{b} *$ with the equation: ${ }^{\circ} \mathrm{Hue}=\tan -1(\mathrm{~b}$ / a), to find out the color division based on oHue can be seen in Table 5 .

Table 5

Color distribution of ${ }^{\circ} \mathrm{Hue}$ (Hutching, 1999)

\begin{tabular}{cc}
\hline${ }^{\mathbf{0}}$ Hue $[\arctan (\mathbf{b} / \mathbf{a})]$ & Color Description \\
\hline $18-54$ & Red $(R)$ \\
$54-90$ & Yellow Red $(Y R)$ \\
$90-126$ & Yellow $(Y)$ \\
$126-162$ & Yellow Green $(Y G)$ \\
$162-198$ & Green $(G)$ \\
$198-234$ & Blue Green $(B G)$ \\
$234-270$ & Blue $(B)$ \\
$270-306$ & Blue Purple $(B P)$ \\
$306-342$ & Purple $(P)$ \\
$342-18$ & Red Purple $(R P)$ \\
&
\end{tabular}

Gel Hardness with Texture Analyzer 
Hardness of gel on agar products using the Brookfield LFRA Texture Analyzer. The type of probe that will be used for gelatin is TA $35 \mathrm{~mm}$. The LFRA Texture Analyzer is set with the provision of a cylinder speed probe of $0.2 \mathrm{~cm} / \mathrm{s}$; trigger $10 \mathrm{~g}$; and $20 \mathrm{~mm}$ distance. The sample is placed on the foundation to be pressed. The probe is mounted in place and the "start" button is pressed to start the testing process. Peak load and final load values appear on the screen.

\section{RESULTS AND DISCUSSION}

\section{A. Organoleptic Test}

\section{Texture Hedonic Quality Test}

The results of the analysis of variance showed that all-natural sweeteners used on the agar texture did not have a significant effect. The average value of hedonic texture quality test can be seen in Table 6.

The average value of the panelist hedonic quality test on the texture ranges from 2.73 to 3.20 (rather easily wrecked). The nature of gel is influenced by the concentration of agar powder, temperature, acidity and sugar content. The higher sugar content causes the gel to become hard with low texture cohesivity (Imeson, 2010).

\section{Texture Hedonic Test}

The results of the analysis of variance showed that all-natural sweeteners used on the agar texture did not have a significant effect. The average value of the texture hedonic test can be seen in Table 6. Based on the results of the texture hedonic test has a preference value between 4.80 (somewhat like) to 5.67 (like).

The higher the concentration of sugar used the more the panelists' preference for texture increases. This is because sugar as a hydrophilic hygroscopic substance will absorb a lot of water (Manullang, 1997), so that the addition of sugar affects the thickness or osmolality and strength of the gel that is formed (BeMiller and Whistler, 1996 in Ramadan, 2011).

\section{Color Hedonic Test}

The results of the analysis of variance showed that all-natural sweeteners used on agar did not have a significant effect. The average value of the color hedonic test can be seen in Table 6. Based on the results of the color hedonic test has a preference value between 4.43 (neutral) to 5.27 (somewhat like).

The color formed on agar is caused by the presence of pigments in each type of natural sweetener used. The higher the concentration of sugar given will increase the formation of pigments as a result of non-enzymatic browning reactions without nitrogen compounds (deMan, 1997 in Ramadan, 2011).

\section{Taste Hedonic Test}

The results of the various analyzes showed that sweetener stevia, sorghum sugar, coconut sugar, and palm sugar did not significantly affect the taste of agar, whereas corn sugar and honey had a very significant effect. The average value of the hedonic taste test can be seen in Table 6 .

Based on the hedonic test results, the taste has a preference value of 2.97 (somewhat dislike) to 5,53 (likes). Panelists' preference for gelatin taste increases with the addition of sugar concentrations.

The 35\% honey treatment showed the panelists' acceptance of the highest agar taste. That is because that honey contains fructose. Fructose is the sweetest sugar type compound (1.12 times sweeter than sucrose) (Sudarmadji, 1982), with the sweet taste covering the aftertaste in the form of bitter taste from bran, so the product is accepted by panelists.

\section{Hedonic Test of Overall Acceptance}

The results of the analysis of variance showed that all types of natural sweeteners did not significantly affect the overall acceptance of agar except honey treatment which had a very significant effect. The average value of the overall acceptance hedonic test can be seen in Table 6. The lowest level of overall acceptance in the stevia sweetener treatment is $0.075 \%$ (neutral) and the highest in the treatment of honey is $35 \%$ (somewhat like).

\section{B. Water content}

The results of the analysis of variance showed that all-natural sweeteners used on agar water levels had a very significant effect. The average value of water content can be seen in Table 7. The highest average water content is in the stevia sweetener treatment of $0.10 \%(92.3542 \%)$ and the lowest in the honey treatment of $35 \%(70.5892 \%)$.

The addition of sugar with high concentrations makes the water content decreases, because sugar is a hygroscopic compound that is able to bind free water into bound water that is difficult to evaporate during cooking (Yulistiani et al., 2013).

The main content of stevia leaves are steviol derivatives, especially stevioside (4-15\%), rebaudioside A (24\%) and C (1-2\%) and dulcocide A (0.4-0.7\%) (Raini and Isnawati, 2011) . In addition, stevia is a sweetener without calories so there is no sucrose content. Therefore, in the treatment of stevia sweetener has a very high water content of $92.3542 \%$ due to the absence of sucrose content that can bind to free water which causes the water to become volatile during cooking so that the resulting water content becomes high. 
Table 6. Hedonic Quality Test Score and Hedonic Test

\begin{tabular}{ccccccc}
\hline $\begin{array}{c}\text { Types of } \\
\text { Natural } \\
\text { Sweeteners }\end{array}$ & $\begin{array}{c}\text { Concentration } \\
\mathbf{( \% )}\end{array}$ & $\begin{array}{c}\text { Texture } \\
\text { (Hedonic Quality) }\end{array}$ & Texture & Color & Taste & $\begin{array}{c}\text { Overall } \\
\text { acceptance }\end{array}$ \\
\hline Stevia & 0,05 & 3,10 & 4,80 & 4,70 & 2,97 & 3,97 \\
sweetener & 0,075 & 3,07 & 4,97 & 4,57 & 3,17 & 3,70 \\
& 0,10 & 3,17 & 5,10 & 4,50 & 3,47 & 3,97 \\
\hline Sorghum & 10 & 2,87 & 5,13 & 4,43 & 3,57 & 4,13 \\
sugar & 15 & 2,77 & 5,33 & 4,73 & 3,87 & 4,17 \\
& 20 & 2,73 & 5,27 & 4,60 & 4,03 & 4,43 \\
\hline Corn sugar & 10 & 2,80 & 5,30 & 4,50 & $3,47^{\mathrm{a}}$ & 4,20 \\
& 15 & 2,73 & 5,50 & 4,60 & $4,23^{\mathrm{b}}$ & 4,47 \\
\hline Coconut & 14 & 5,83 & 5,43 & 4,60 & $4,53^{\mathrm{b}}$ & 4,70 \\
\hline sugar & 15 & 2,93 & 5,23 & 5,03 & 4,43 & 4,87 \\
& 16 & 3,00 & 5,33 & 5,23 & 4,77 & 4,87 \\
\hline Palm sugar & 7,50 & 3,10 & 5,33 & 5,17 & 4,63 & 5,00 \\
\hline Honey & 10 & 3,17 & 4,97 & 4,93 & 3,73 & 4,27 \\
& 12,50 & 3,10 & 5,00 & 5,10 & 4,23 & 4,67 \\
& 15 & 3,00 & 5,33 & 5,17 & 4,50 & 4,83 \\
\hline
\end{tabular}

Note: Numbers followed by the same lowercase letters in the same column show no significant difference at the $5 \%$ level according to the DNMRT test.

Texture value (hedonic quality test): $1=$ Very easy to break, 2 = Not easily broken, $3=$ Somewhat easily broken, $4=$ Easy to break, $5=$ Very easy to break.

Value of texture, color, taste and overall acceptance (hedonic test): $1=$ Very dislike, $2=$ Dislike, $3=$ Somewhat dislike, 4 $=$ neutral, $5=$ somewhat like, $6=$ like, $7=$ really like

\section{Acidity ( $p H)$}

The results of the analysis of the variance showed that all-natural sweeteners used on agar $\mathrm{pH}$ had a very significant effect. The average value of $\mathrm{pH}$ can be seen in Table 7. Increasing the $\mathrm{pH}$ in line with the increase in the amount of sucrose added due to the addition of sugar, $\mathrm{H}+$ ions derived from organic acids also undergo dilution, so that $\mathrm{H}+$ ions that form acid will be reduced and the $\mathrm{pH}$ of the material will increasing (Pertiwi and Wahono, 2014). But this is not suitable for stevia sweetener, because stevia sweetener contains glycoside which has a sweet taste but does not produce calories and has a $\mathrm{pH}$ of 5-6 (Buchori, 2007) so that the use of even a small amount of the resulting $\mathrm{pH}$ value is already high.

\section{Total Dissolved Solids}

The results of the analysis of variance showed that all- natural sweeteners used on the total dissolved solids of agar had a very significant effect. The average total dissolved solids can be seen in Table 7. The total dissolved solids tend to increase with increasing sugar concentration. This is consistent with Buckle (1987) in Yulistiani (2013), stating the higher addition of sucrose results in higher total dissolved solids.

The lowest average value of total dissolved solids in the stevia sweetener treatment was $0.10 \%$, which was $1.61 \%$. The main content of stevia leaves are steviol derivatives, especially stevioside (4$15 \%)$, rebaudioside $\mathrm{A}(24 \%)$ and $\mathrm{C}(1-2 \%)$ and dulcocide A $(0.4-0.7 \%)$, besides stevia as a sweetener without calories and without the addition of chemicals (Raini and Isnawati, 2011) make the measured component of total dissolved solids very small because there is no sucrose content in stevia sweeteners so the resulting value is also very small compared to other natural sweetener treatments.

\section{E. Crude Fiber Content}

The results of the analysis of variance showed that all-natural sweeteners used on agar fiber levels did not have a significant effect. This can be caused because the natural sweetener used does not contain high fiber. The average value of crude fiber content can be seen in Table 7 .

Stevia sweetener comes from stevia leaf extract. In Widodo et al research. (2015) stated that the crude fiber content of stevia leaf extract was $1,304 \%$. The levels of crude fiber from stevia leaf extract makes high levels of crude fiber agar for the stevia sweetener treatment.

\section{F. Total Sugar}

The results of the various analyzes showed that all the natural sweeteners used on the total sugar agar were very significant. The average value of total sugar can be seen in Table 7 .

In the $0.10 \%$ stevia sweetener treatment has a total sugar value of $0.74 \%$ this is assumed because the stevia sweetener used contains 97\% steviol glycosides so that in the stevia sweetener treatment there is still a sugar content. The total value of sugar increases with increasing concentration of the treatment used. This was also explained by Pratama et al., (2011) in a research on syrup making that sugar concentration affected the total value of sugar 
produced. The more concentration of sugar added will increase the total sugar available, because the solubility of sugar is a sugar solution consisting of mostly sucrose and some non-sucrose components, so that by adding sugar from the outside it will automatically increase its sucrose part.

Table 7

Average values of water content, $\mathrm{pH}$, total dissolved solids, crude fiber content, total sugar

\begin{tabular}{|c|c|c|c|c|c|}
\hline $\begin{array}{c}\text { Types of Natural } \\
\text { Sweeteners }\end{array}$ & Water content $(\%)$ & pH & $\begin{array}{c}\text { TDS } \\
\left({ }^{0} \text { Brix }\right)\end{array}$ & $\begin{array}{l}\text { Crude fiber } \\
\text { content }(\%)\end{array}$ & $\begin{array}{c}\text { Total Sugar } \\
(\%)\end{array}$ \\
\hline Stevia sweetener & $92,3542 \pm 0,7961^{\mathrm{d}}$ & $5,60 \pm 0,07^{\mathrm{c}}$ & $1,61 \pm 0,10^{\mathrm{a}}$ & $1,304 \pm 0,569$ & $0,74 \pm 0,08^{\mathrm{a}}$ \\
\hline Sorghum sugar & $71,8920 \pm 1,6508^{\mathrm{a}}$ & $4,61 \pm 0,02^{\mathrm{a}}$ & $21,50 \pm 1,44^{d}$ & $0,978 \pm 0,020$ & $5,81 \pm 1,01^{\mathrm{bc}}$ \\
\hline Corn sugar & $75,6811 \pm 1,3499^{b}$ & $5,70 \pm 0,07^{\mathrm{c}}$ & $21,28 \pm 1,21^{\mathrm{d}}$ & $0,971 \pm 0,016$ & $7,00 \pm 1,21^{\mathrm{c}}$ \\
\hline Coconut sugar & $76,5283 \pm 1,0515^{\mathrm{bc}}$ & $4,82 \pm 0,34^{\mathrm{ab}}$ & $17,67 \pm 0,50^{\mathrm{c}}$ & $0,971 \pm 0,016$ & $3,88 \pm 1,06^{\mathrm{b}}$ \\
\hline Palm sugar & $79,0544 \pm 1,9895^{\mathrm{c}}$ & $4,69 \pm 0,06^{\mathrm{a}}$ & $15,17 \pm 0,88^{\mathrm{b}}$ & $0,987 \pm 0,022$ & $3,86 \pm 0,98^{\mathrm{b}}$ \\
\hline Honey & $70,5892 \pm 2,2236^{\mathrm{a}}$ & $4,99 \pm 0,05^{\mathrm{b}}$ & $25,61 \pm 2,38^{\mathrm{e}}$ & $0,955 \pm 0,006$ & $6,88 \pm 1,53^{\mathrm{c}}$ \\
\hline
\end{tabular}

Note: Numbers followed by the same lowercase letters in the same column show no significant difference at the $5 \%$ level according

to

the

natural sweetener treatn

\section{G. Syneresis}

The results of the analysis of variance showed that all-natural sweeteners used for agar syneresis had no real effect. The average value of syneresis on the 7 th and 14th day can be seen in Table 8 .

The syneresis of agar increases with increasing storage time because during storage the aggregation between the double helix polymer chains continues to occur. Aggregation is caused by the movement of the polymer chain in the gel system.

The heating process with a temperature higher than the temperature of the formation of the gel will cause the polymer so that the solution becomes a random coil (random) because the kinetic energy generated by heat prevents the polymer from forming a helix structure (Sadar, 2004). The polymer chains that meet each other cause the formation of hydrogen bonds between the polymer chains so that the structure of the network is denser and the space to trap water is smaller. As a result, water that was originally trapped in the space between the polymer chains is released from the gel system (Therkelsen, 2003).

\section{H. Color Analysis}

The results of the analysis of variance showed that the addition of natural sweeteners had a very significant influence on the respective values of $\mathrm{L} *$, $\mathrm{a}^{*}$ and $\mathrm{b} *$. The average values of $\mathrm{L} *, \mathrm{a} *$ and $\mathrm{b} *$ can be seen in Table 9 .

The $\mathrm{L} *$ value indicates that all treatments are directed towards black (dark). The resulting a* value is positive $(+)$ which indicates that all treatments are directed towards red. The resulting $b$ * value is positive $(+)$ which indicates that allthe yellow.
Based on Table 9, the addition of various natural sweeteners to agar has the same color as indicated by the color description, namely Yellow Red (YR). The color produced in agar products comes from natural bran and sweeteners used, because these ingredients contain pigments that affect the color of the final product. The higher the concentration of sugar given will increase the formation of pigments as a result of non-enzymatic browning reactions without nitrogen compounds (deMan, 1997 in Ramadan, 2011).

\section{Gel Hardness}

Based on the results of the analysis of the variety showed that all-natural sweeteners used in gel agar hardness had no real effect. The average value of gel hardness can be seen in Table 8 .

The highest average gel hardness value in the $16 \%$ coconut sugar treatment is $645.9 \mathrm{gF}$ and the lowest average gel hardness value in the $20 \%$ corn sugar treatment is $539.9 \mathrm{gF}$. In research (Mithania, 2017), it is stated that the gel hardness of gelatin with the addition of red yeast rice and rice bran has a value of $964.25 \mathrm{gF}$, while the hardness of gel without treatment has a value of $2535.5 \mathrm{gF}$. The average value of gel hardness in this study was lower than the average value of gel hardness in previous studies which indicated that the agar product had a softer texture. The amount of water contained in food affects the texture and level of gel hardness, the more water levels increase the easier it is to undergo syneresis so that the gel hardness will decrease (Murdinah, 2010). 
Table 8

Average Value of Syneresis and Gel Hardness

\begin{tabular}{cccc}
\hline $\begin{array}{c}\text { Types of Natural } \\
\text { Sweeteners }\end{array}$ & Syneresis on Day 7 & Syneresis on Day 14 & Gel Hardness \\
\hline Stevia sweetener & $0,4448 \pm 0,1658$ & $0,8309 \pm 0,1586$ & $577,1 \pm 8,4$ \\
Sorghum sugar & $0,3990 \pm 0,0972$ & $0,8932 \pm 0,0141$ & $557,8 \pm 76,2$ \\
Corn sugar & $0,3329 \pm 0,1319$ & $0,5978 \pm 0,1533$ & $539,9 \pm 79,9$ \\
Coconut sugar & $0,2907 \pm 0,1085$ & $0,7522 \pm 0,1312$ & $645,9 \pm 81,9$ \\
Palm sugar & $0,1624 \pm 0,0150$ & $0,8291 \pm 0,2857$ & $614,9 \pm 5,9$ \\
Honey & $0,4259 \pm 0,1154$ & $0,8345 \pm 0,0945$ & $558,7 \pm 74,3$ \\
\hline
\end{tabular}

Table 9

Average Values of $\mathrm{L} *, \mathrm{a} *, \mathrm{~b} *{ }^{\circ} \mathrm{Hue}$ and Color Descriptions

\begin{tabular}{|c|c|c|c|c|c|}
\hline $\begin{array}{c}\text { Types of Natural } \\
\text { Sweeteners }\end{array}$ & $\mathbf{L}^{*}$ & $a^{*}$ & $\mathbf{b}^{*}$ & ${ }^{\mathbf{0}} \mathrm{Hue}$ & Deskripsi Warna* \\
\hline Stevia sweetener & $35,38^{\mathrm{e}}$ & $5,32^{\mathrm{c}}$ & $22,83^{\mathrm{c}}$ & 75,88 & Yellow Red (YR) \\
\hline Sorghum sugar & $33,33^{\mathrm{c}}$ & $4,82^{\mathrm{ab}}$ & $22,03^{\mathrm{ab}}$ & 77,66 & Yellow Red (YR) \\
\hline Corn sugar & $33,66^{\mathrm{c}}$ & $4,92^{\mathrm{b}}$ & $22,10^{\mathrm{b}}$ & 77,45 & Yellow Red (YR) \\
\hline Coconut sugar & $32,68^{\mathrm{b}}$ & $5,59^{d}$ & $22,99^{\mathrm{c}}$ & 76,34 & Yellow Red (YR) \\
\hline Palm sugar & $32,06^{\mathrm{a}}$ & $5,40^{\mathrm{c}}$ & $21,85^{\mathrm{a}}$ & 76,12 & Yellow Red (YR) \\
\hline Honey & $33,53^{\mathrm{cd}}$ & $4,69^{\mathrm{a}}$ & $21,81^{\mathrm{a}}$ & 77,86 & Yellow Red (YR) \\
\hline
\end{tabular}

Note: Numbers followed by the same lowercase letters in the same column show no significant difference at the $5 \%$ level according to the DNMRT test.

\section{CONCLUSION}

Based on the results of research that has been done, it can be concluded as follows:

1. The best concentration of organoleptic properties in making agar with the addition of bran is stevia $0.10 \%$ sweetener, $20 \%$ sorghum sugar, $20 \%$ corn sugar, $16 \%$ coconut sugar, $12.5 \%$ palm sugar and $35 \%$ honey.

2. The addition of various types of natural sweeteners to the making of agar with the addition of bran has a significant effect on taste and overall acceptance but has no significant effect on texture and color.

3. The addition of various types of natural sweeteners in the making of agar with the addition of rice bran significantly affected the water content, $\mathrm{pH}$, total dissolved solids, total sugar, and color analysis, but did not significantly affect the levels of crude fiber, syneresis and gel hardness.

4. The best treatment for making agar with the addition of bran is honey $35 \%$ with a value of liking the texture and taste, as well as the value of rather liking the color and overall acceptance, water content of $70.5892 \%$; $\mathrm{pH} 4.99$; TPT 25.61 0Brix; crude fiber content of $0.955 \%$; total sugar $6.88 \%$; 7 th day syneresis $0.4259 \%$; syneresis of the 14 th day $0.8345 \%$; yellow red color description; and gel hardness of $558.7 \mathrm{gF}$.

\section{References}

[1] Azzmi. 2012. Pembuatan Mi Bekatul Beras Merah Substitusi Tepung Ubi Jalar Ungu (Ipomoea babatas blackie) Kaya
Antioksidan. Skripsi. Fakultas Pertanian. Universitas Sebelas Maret. Surakarta.

[2] Badan Pengawasan Obat dan Makanan. 2005. Peraturan Kepala Badan Pengawas Obat dan Makanan Republik Indonesia Nomor HK 00.0S.52.068 Tentang Ketentuan Pokok Pengawasan Pangan Fungsional. Badan Pengawasan Obat dan Makanan. Jakarta.

[3] Buchori L. 2007. Pembuatan Gula Non Karsinogenik, Non Kalori dari Daun Stevia. Jurnal Reaktor Vol.11(2) : 57-60.

[4] Cyntia. 2018. Pengaruh Konsentrasi Karagenan dan Gula Stevia Terhadap Karakteristik Fisikokimia dan Organoleptik Minuman Jeli Nanas Sweet Cayenne. Skripsi. Fakultas Teknologi Pertanian. Universitas Katolik Widya Mandala Surabaya. Surabaya.

[5] Hutching JB.1999. Food Color and Appearance 2nd edition A Chapman and HallFood Science Book. Aspen sPublition. Maryland.

[6] Imeson A. 2010. Food Stabilisers, Thickeners, and Gelling Agent. Willey Blackwell Publishing Ltd. United Kingdom.

[7] Irawan B dan Sutrisna. 2011. Prospek Pengembangan Sorgum di Jawa Barat Mendukung Diversifikasi Pangan. Jurnal Forum Penelitian Agro Ekonomi. Vol. 29(2) : 99-113.

[8] Kusumastuti dan Ayustaningwarno. 2013. Pengaruh Penambahan Bekatul Beras Merah Terhadap Kandungan Aktivitas Antioksidan dan Kesukaan Sosis Tempe. Journal of Nutrition College Vol.2(1): 2734. 
[9] Manullang M. 1997. Food Carbohydrates. Teknologi Pangan. Fakultas Industri Universitas Pelita Harapan. Jakarta.

[10] Mithania D. 2017. Produk Agar-Agar dengan Penambahan Bekatul dan Angkak sebagai Alternatif Cemilan Penurun Kolesterol. Skripsi. Fakultas Teknologi Pertanian. Institut Pertanian Bogor. Bogor.

[11] Moko EM, Purnomo HKJ, dan Ijong FG. 2014. Phytochemical Content and Antioxidant Properties of Colored and Non Colored Varieties of Rice Bran from Minahasa. International Food Research Journal Vol. 21(3) : 1053-1059. Sulawesi Utara.

[12] Murdinah MS. 2010. Pemanfaatan Rumput Laut dan Fikokoloid untuk Produk Pangan dalam Rangka Peningkatan Nilai Tambah dan Diversifikasi Pangan. Laporan Akhir Program Insentif Peningkatan Kemampuan Peneliti dan Perekayasa. Kementerian Kelautan dan Perikanan. Jakarta.

[13]Pertiwi, M.F.D dan Wahono H.S. 2014. Pengaruh Proporsi (Buah : Sukrosa) dan Lama Osmosis terhadap Kualitas Sari Buah Stroberi (Fragaria vesca L.). Jurnal Pangan dan Agroindustri Vol. 2(2) : 82-90.

[14] Pratama S.B, Wijana S, Febriyanto A. 2011. Studi Pembuatan Sirup Tamarillo (Kajian Perbandingan Buah dan Konsentrasi Gula). Jurnal Industria Vol.1(3) : 181 - 194.

[15] Raini M dan Isnawati A. 2011. Kajian: Khasiat dan Keamanan Stevia sebagai Pemanis Pengganti Gula. Media Litbang Kesehatan Vol. 21(4): 145-156.

[16] Ramadan W. 2011. Pemanfaatan AgarAgar Tepung sebagai Texturizer pada Formulasi Selai Jambu Biji Merah (Psidium Guajava L.) Lembaran dan Pendugaan Umur Simpannya. Skripsi. Fakultas Perikanan dan Ilmu Kelautan. Institut Pertanian Bogor. Bogor.

[17] Sadar, L. N. 2004. Rheological and Textural Characteristics of Copolymerized Hydrocolloidal Solutions Containing Curdlan Gum. Thesis. Faculty of the Graduate School. University of Maryland. College Park.

[18] Sapriyanti R, Nurhartadi E, dan Ishartani D. 2014. Karakteristik Fisikokimia dan Sensori Velva Tomat (Lycopersicum esculentum Mill) dengan Pemanis Madu. Jurnal Teknologi Hasil Pertanian Vol.7(1) : 59-69.

[19] Sirajuddin. 2010. Komponen Hasil dan Kadar Gula Jagung Manis (Zea mays saccharata) Terhadap Pemberian Nitrogen dan Zat Tumbuh Hidrasil. Skripsi. Fakultas Pertanian. Universitas Tadulako. Palu.
[20] Sudarmadji. S. 1982. Bahan-Bahan Pemanis. Agritech. Yogyakarta.

[21] Syukroni I, Yulianti K, Baehaki A. 2013. Karakteristik Nata de seawees (Eucheuma cottonii) dengan Perbedaan Konsentrasi Rumput Laut dan Gula Aren. Jurnal Fishtech Vol.2(1) : 1-8.

[22] Therkelsen, G. H. 2003. Carrageenan. Academia Press, Inc. San Diego.

[23] Widodo, Munawaroh N, Indratiningsih. 2015. Produksi Low Calorie Sweet BioYoghurt dengan Penambahan Ekstrak Daun Stevia (Stevia rebaudiana) sebagai Pengganti Gula. Jurnal Agritech, Vol.35(4): 464-473.

[24] Yanto T, Karseno, dan Purnamasari M. 2015. Pengaruh Jenis dan Konsentrasi Gula Terhadap Karakteristik Fisikokimia dan Sensori Jelly Drink. Jurnal Teknologi Hasil Pertanian Vol. 8(2) : 123-129.

[25] Yulistiani R, Murtiningsih, Mahmud M. 2013. Peran Pektin dan Sukrosa pada Selai Ubi Jalar Ungu. Jurnal Teknologi Pangan Vol. 5(2): 114-120. 